\title{
Hours restriction: mentors' point of view
}

\author{
Diego Adão^ \\ Emergency Department of Surgery, Escola Paulista de Medicina - Federal University of Sao Paulo, Sao Paulo, Brazil \\ Correspondence to: Diego Adão. Acute Care Surgeon, MSc, Assistant Surgeon of Emergency Department of Surgery, Escola Paulista de Medicina - \\ Federal University of Sao Paulo, Rua Napoleão de Barros, 715, 2nd floor, Sao Paulo 04024-002, Brazil. Email: diegoepm73@yahoo.com.br.
}

Received: 04 May 2021; Accepted: 26 May 2021; Published: 30 September 2021.

doi: $10.21037 /$ asj-21-25

View this article at: http://dx.doi.org/10.21037/asj-21-25

\section{Introduction}

The work hour restriction for resident physicians in general surgery programs is a concern of the main medical education agencies (1). The duty hour restriction intends to promote a safer environment for patients and residents (2). However, several groups have questioned the real outcomes of this reform, rising up a controversy in the medical community regarding risks and benefits of work hour restrictions $(3,4)$, with many barriers been reported by surgery trainees (5).

I am the supervisor of two medical residency programs at a large university center in Brazil: 48 residents from 2-year General Surgery program, and 18 residents from 3-year Emergency Medicine program. Our institution has established as a standard an average of 60-hour workweek, 24-hour maximum shift duration, and a mandatory break between shifts of 6 hours. After six consecutive years in this position, I have some considerations.

\section{Benefits}

There is some evidence suggesting restriction of hours programs brings more comfort and quality of life to residents. A US multi-institutional study showed a significantly lower mean psychologic distress among surgery residents after the implementation of the 80 -hour workweek, and a reduction from $38 \%$ to $24 \%$ in the percentage of surgery residents scoring equal to or above the 90th percentile of the normative cohort for clinical psychologic distress (6). A systematic review published in 2005 confirmed this data (7), however new recent studies did not endorse these findings $(4,8)$.

My residents claim to have more time for rest, restorative hours of sleep, leisure activities, time to solve personal problems in commercial establishments, and free time with family and friends. I perceive residents to be less stressed (mainly in night shifts), improvement in communication skills (less violent communication), lower levels of burnout, and greater willingness to work. Although residents claim that they had more free time to study after duty hour restriction, I did not notice a significant improvement in their test performance along the year, similar to literature (8).

\section{Disadvantages}

The main disadvantage that I realized was a break in the continuity of assistance. Some residents did not understand that time restriction is a flexible concept and not a restricted one. In specific situations, such as in a ward rotation, some residents threaten to interrupt their activities due to timeouts. They leave the hospital without knowing the result of the upper gastrointestinal endoscopy of the patient with intestinal bleeding; they agree to take Science of it only in the next day. We tolerate some less serious cases, but we prohibit the exchange of residents during surgery, even if the procedure extends beyond the scheduled shift period.

Because of patient safety concerns, recent studies reported residents' disagreement and violation of duty hour policies. An interview involving 1,011 surgery residents showed that $67.6 \%$ of trainees were noncompliant with duty hours week work (they intentionally exceeded the

^ ORCID: 0000-0002-2385-0193. 
weekly workload), and they were 2.18 times more likely to falsely report hours than all other specialties (9). Matulewicz et al. reported that $25.3 \%$ of surgery residents perceived a negative effect of duty hour restrictions on patient safety (10), which would justify this willingness to work beyond the recommended.

\section{Half term}

I believe that a time restriction system should exist in all residency programs, especially those with high work and emotional load, such as surgery and emergency medicine. There is countless evidence that overwork impairs performance, similar to aviation. On the one hand, some residents are workaholics; on the other hand, some staffs are traditional and still believe that the medical residency should be the resident's residence, as the name suggests. A force majeure needs to put a limit on these two types of mindsets.

Instead, some residents of the new generation feel free to interrupt the continuity of assistance regardless of the risks to patients, which should be strongly discouraged. They have no sense of commitment and responsibility, nor common sense.

Therefore, the restriction of working hours should be a weekly average, with some heavier days and others lighter, shifts followed by rest and planned days off. Mentors must know in which activities to invest the residents' time, focusing on situations where the extrapolation of hours is justified. My arguments are based on a single-center experience, suffering the limitation of the risk of bias from a regionalism point of view.

\section{Acknowledgments}

Funding: None.

\section{Footnote}

Provenance and Peer Review: This article was commissioned by the Guest Editors (Fernando A. M. Herbella and Volha Raznitsyna) for the series "Modern Challenges in the Education of Young Surgeons: the Two Sides of the Coin" published in AME Surgical fournal. The article has undergone external peer review.

Conflicts of Interest: The author has completed the ICMJE uniform disclosure form (available at https://asj.amegroups. com/article/view/10.21037/asj-21-25/coif). The series "Modern Challenges in the Education of Young Surgeons: the Two Sides of the Coin" was commissioned by the editorial office without any funding or sponsorship. The author has no other conflicts of interest to declare.

Ethical Statement: The author is accountable for all aspects of the work in ensuring that questions related to the accuracy or integrity of any part of the work are appropriately investigated and resolved.

Open Access Statement: This is an Open Access article distributed in accordance with the Creative Commons Attribution-NonCommercial-NoDerivs 4.0 International License (CC BY-NC-ND 4.0), which permits the noncommercial replication and distribution of the article with the strict proviso that no changes or edits are made and the original work is properly cited (including links to both the formal publication through the relevant DOI and the license). See: https://creativecommons.org/licenses/by-nc-nd/4.0/.

\section{References}

1. Ingrid Philibert SA. The ACGME 2011 Duty Hour Standards: Enhancing Quality of Care, Supervision, and Resident Professional Development Accreditation Council for Graduate Medical Education (ACGME). Chicago, IL: ACGME; 2011.

2. Philibert I, Friedmann P, Williams WT, et al. New requirements for resident duty hours. JAMA 2002;288:1112-4.

3. Patel MS, Volpp KG, Small DS, et al. Association of the 2011 ACGME resident duty hour reforms with mortality and readmissions among hospitalized Medicare patients. JAMA 2014;312:2364-73.

4. Ahmed N, Devitt KS, Keshet I, et al. A systematic review of the effects of resident duty hour restrictions in surgery: Impact on resident wellness, training, and patient outcomes. Ann Surg 2014;259:1041-53.

5. Grabski DF, Goudreau BJ, Gillen JR, et al. Compliance with the Accreditation Council for Graduate Medical Education duty hours in a general surgery residency program: Challenges and solutions in a teaching hospital. Surgery 2020;167:302-7.

6. Zaré SM, Galanko JA, Behrns KE, et al. Psychologic well-being of surgery residents after inception of the 80-hour workweek: a multi-institutional study. Surgery 2005;138:150-7. 
7. Fletcher KE, Underwood W 3rd, Davis SQ, et al. Effects of work hour reduction on residents' lives: a systematic review. JAMA 2005;294:1088-100.

8. Bolster L, Rourke L. The Effect of Restricting Residents' Duty Hours on Patient Safety, Resident Well-Being, and Resident Education: An Updated Systematic Review. J Grad Med Educ 2015;7:349-63.

doi: $10.21037 /$ asj-21-25

Cite this article as: Adão D. Hours restriction: mentors' point of view. AME Surg J 2021;1:11.
9. Drolet BC, Schwede M, Bishop KD, et al. Compliance and falsification of duty hours: reports from residents and program directors. J Grad Med Educ 2013;5:368-73.

10. Matulewicz RS, Odell DD, Chung JW, et al. Association Between Resident Perceptions of Patient Safety and Duty Hour Violations. J Am Coll Surg 2017;224:113-7.e4. 